\title{
Evaluation of Environment Investment Efficiency in Coal Firms
}

\author{
Xiuying XING \\ Hohhot Vocational College, Hohhot, PRC \\ Jiexin GUO \\ Department of Economics and Management, Inner Mongolia University, Hohhot, PRC
}

\begin{abstract}
This paper examines explores reason for the inefficiency of environmental investment of 28 coal firms listed in China during the period 2004-2010. We estimate the expectation investment on environment in the context of the residual model of Richardson (2006). The results suggest that $41.07 \%$ of the observations are over-investment while the others are under-investment. The determinants of inefficiency are financing restrains and other projects selection. We find the major factor influenced the investment on environment protection and treatment in China is whether there are governments' guidelines and laws.
\end{abstract}

KEYWORD: Environment Investment; Efficiency; Coal Firms

\section{INSTRUCTIONS}

China is one of the largest countries that have tremendous riches in coal while have the most serious environmental problems. A key focus of the prosperity of economics is the energy reserves and energy consumption. So it is extremely hard to see the predominance of coal in China' energy structure be changed. However, despite of the increase in environment treatment spending, there has been little empirical evidence to testify the investment efficiency in such firms in China. As described in Statement of Financial Reporting, firms that listed in China exchange stock should provide information that is useful to present and potential investors in making rational investment decisions. Considering the level of information disclosure, we pick up the coal firms as our samples. In this paper, we provide evidence on whether the coal firms exhibit investment efficiency.

There exist many researchers in china to make contribution on the environmental investment with a different perspective from the west where the institutional framework is different from China. Zhang and Zuo[3] (2007) suggested endogenous growth mechanism could resolve problems in coal firms with environmental puzzle. Wang[2] (2009) lay a good theoretical analysis framework of evaluation on investment benefit and renew the model based on model of Sun to improve investment efficiency. Zhang and Song[4] (2009) considered lack of formal evaluation system in the country level the major reason why there were lots of problem being resolved.

Different from prior studies, despite of researching theoretically, this paper focuses on utilizing accounting information to better measure the efficiency of inefficiency of investment on environment protection, thereby allowing a more powerful test of estimated data to make explanation for why firm level investment is of efficiency of inefficiency. We contribute to prior study by using data set to testify whether investment efficiency exists in coal firms in China with model created by Richardson[1] (2006).

\section{DATA AND VARIABLE DESCRIPTIONS}

\subsection{Data source and sample selection}

Our primary data source for this study is CCER Database and CSMAR database, respectively. We obtain annual financial accounting variables, monthly deal information from CCER and CSMAR database. The empirical analysis of the environment investment is conducted on a data set of 196 observations from coal firms listed in Shanghai and Shenzhen Stock Exchange in China during the period 2004-2010.Due to the data availability of firm-level environmental investment from the annual reports, the sample is limited to firms mainly operating coal exploiting business and the final sample comprising 196 firm-year observations. In order to mitigate the influence of outliers, we 
winsorize all continuous variables at the $1 \%$ and $99 \%$ levels by year at the firm-year level.

This paper will quantize the efficiency in our samples. The model that we adopt is from Richardson[1](2006) whose paper built an investment expectation model that captured firm specific growth opportunities and measures of financing constraints. If the sign of the residual is positive, we could deduce that it is over-investment; otherwise, it is under-investment.

\subsection{The model}

We build the model as follows:

$$
\begin{aligned}
I N V_{t} & =\alpha_{0}+\alpha_{1} \text { Growth }_{t-1}+\alpha_{2} \text { Lev }_{t-1}+\alpha_{3} \text { Cash }_{t-1} \\
& +\alpha_{4} \text { Age }_{t-1}+\alpha_{5} \text { Size }_{t-1}+\alpha_{6} \text { RET }_{t-1} \\
& +\alpha_{7} I N V_{t-1}+\varepsilon
\end{aligned}
$$

Our main measure of investment variable INVt is defined as the total investment in the year t. We use seven variables to control for firm specific characteristics. These widely used controls include Growth $_{\mathrm{t}-1}$, which is the ratio of sales by sales last year (we use an alternative variable, Tobin's Q to test the robustness, and have the similar results); $\operatorname{Lev}_{\mathrm{t}-1}$, which is the ratio of total debt by total assets in year $\mathrm{t}$; $\mathrm{Cash}_{\mathrm{t}-1}$, which is defined cash hold level; Age $_{t-1}$, the years since date of IPO to year ${ }_{t-1}$; Size $_{t-1}$; $\mathrm{RET}_{\mathrm{t}-1}$, monthly return to shareholders; We get the expectation investment on environmental protection by regression in the model. If the sign of the residual is positive, we could deduce that it is overinvestment; otherwise, it is the opposite. In Table.1

\begin{tabular}{|c|c|}
\hline Name & Meaning \\
\hline $\mathrm{INV}_{\mathrm{t}}$ & Change of environment investment/ total assets \\
\hline Growth $_{\mathrm{t}-1}$ & Tobin' $Q$ in year ${ }_{t-1}$ \\
\hline $\operatorname{Lev}_{\mathrm{t}-1}$ & The debt to assets ratio in the year ${ }_{t-1}$ \\
\hline $\mathrm{Cash}_{\mathrm{t}-1}$ & Cash holdings in the year $\mathrm{t}-1$ \\
\hline $\mathrm{Age}_{\mathrm{t}-1}$ & The years since date of IPO to year $\mathrm{t}_{\mathrm{t}-1}$ \\
\hline Size $_{\mathrm{t}-1}$ & The natural $\log$ of total assets in the year ${ }_{t-1}$ \\
\hline $\operatorname{RET}_{\mathrm{t}-1}$ & Adjusted monthly stock returns (May-Apr) \\
\hline Year & Indicator variables of annual fixed effects. \\
\hline $\mathrm{OINV}_{\mathrm{t}}$ & Over-investment, the residual is positive \\
\hline $\mathrm{UINV}_{\mathrm{t}}$ & Under-investment, the residual is negative \\
\hline
\end{tabular}
we show the variables in the text

Table 1. Variables

\subsection{Empirical results}

\subsubsection{Correlation and summary statistics}

Table 2 presents relationships between the variables. It can be seen the correlation between $\mathrm{NV}_{t}$ and $\mathrm{INV}_{\mathrm{t}-1}$ is negative and significant. Both Cash $\mathrm{t}_{\mathrm{t}-1}$ and Size $_{\mathrm{t}-1}$ show positive correlation with INVt; finally,
$\mathrm{NV}_{\mathrm{t}}$ appears to be negative correlated with Growth $_{\mathrm{t}-1}, \quad \mathrm{LeV}_{\mathrm{t}-1}, \quad \mathrm{Age}_{\mathrm{t}-1}$ and $\mathrm{RET}_{\mathrm{t}-1}$, but not significant.

Table 2. Correlation matrixes

\begin{tabular}{|l|l|l|l|l|l|l|}
\hline & $\mathrm{INV}_{\mathrm{t}}$ & $\mathrm{Gro}_{\mathrm{t}-1}$ & $\mathrm{LeV}_{\mathrm{t}-1}$ & $\mathrm{Ca}_{\mathrm{t}-1}$ & $\mathrm{Ag}_{\mathrm{t}-1}$ & $\mathrm{~S}_{\mathrm{t}-1}$ \\
\hline $\mathrm{INV}_{\mathrm{t}}$ & 1 & & & & & \\
\hline $\mathrm{Gro}_{\mathrm{t}-1}$ & -0.08 & 1 & & & & \\
\hline Lev $_{\mathrm{t}-1}$ & -0.03 & -0.12 & 1 & & & \\
\hline $\mathrm{Ca}_{\mathrm{t}-1}$ & 0.00 & 0.09 & $-0.18^{*}$ & 1 & & \\
\hline $\mathrm{Age}_{\mathrm{t}-1}$ & -0.05 & 0.13 & -0.04 & $-0.13^{*}$ & 1 & \\
\hline Size $_{\mathrm{t}-1}$ & 0.05 & $-0.20^{*}$ & $0.19^{*}$ & $-0.18^{*}$ & -0.04 & 1 \\
\hline $\mathrm{RE}_{\mathrm{t}-1}$ & -0.01 & $0.77^{*}$ & -0.03 & 0.02 & -0.02 & 0.0 \\
\hline $\mathrm{INV}_{\mathrm{t}-1}$ & $-0.33^{*}$ & -0.02 & -0.07 & 0.01 & -0.08 & 0.1 \\
\hline
\end{tabular}

Table 3 presents the descriptive statistics for the variables used in our analysis. We can see from this table, distribution of environmental protection investment is more evenly; the standard deviation of asset-liability ratio and cash holdings is smaller, indicating that the financial condition of companies that conducted investment in environmental protection is similarity; companies listed on the age and firm size are quite different, show that is not only larger, longer listed companies investing in environmental protection, which reflect the impact of national policies on investment in environmental protection.

Table 3. Descriptive statistics

\begin{tabular}{|l|r|l|l|l|l|l|l|}
\hline & Mean & SD & Min & $25 \%$ & Medi & $75 \%$ & Max \\
\hline INV & 0. & 0.02 & -0.1 & 0 & 0 & 0 & 0.12 \\
\hline Growth & 1.41 & 0.52 & 0.91 & 1.00 & 1.20 & 1.73 & 4.06 \\
\hline Lev & 0.55 & 0.13 & 0.22 & 0.45 & 0.56 & 0.68 & 0.82 \\
\hline Cash & 0.10 & 0.06 & 0.01 & 0.06 & 0.10 & 0.14 & 0.28 \\
\hline Age & 9.96 & 2.16 & 4 & 5 & 10 & 13 & 17 \\
\hline Size & 23.0 & 1.20 & 18.9 & 20.2 & 23.07 & 24 & 27.4 \\
\hline RET & 0.89 & 1.41 & -0.8 & -0.1 & 0.82 & 1.67 & 6.79 \\
\hline
\end{tabular}

Table 4 presents the descriptive statistics for environmental protection investment. We can see that in 196 observations which are selected from seven years by regression analysis the 112 observations that from the later four years, there are 46 companies indicate over-investment, and 66 companies indicate under-investment. In 2007, under-investment companies accounted for $30.30 \%$ of observations; in 2008, over-investment companies accounted for $21.74 \%$ of observations; therefore, we informed that companies investment in environmental protection between 2007 and 2008 have a greater change. 
Table 4. Descriptive statistics for environmental protection investment

\begin{tabular}{|l|l|l|l|l|l|l|l|l|}
\hline & \multicolumn{4}{|l|}{ OverINV $_{\mathrm{t}}$} & \multicolumn{3}{l|}{ UnderINV $_{\mathrm{t}}$} \\
\hline & 07 & 08 & 09 & 10 & 07 & 08 & 09 & 10 \\
\hline Mean & 0.01 & 0.01 & 0.01 & 0.01 & 0.01 & 0.01 & 0.01 & 0.01 \\
\hline SD & 0.01 & 0.02 & 0.01 & 0.01 & 0.02 & 0.01 & 0.02 & 0.01 \\
\hline Min & 0.00 & 0.01 & 0.00 & 0.01 & 0.00 & 0.00 & 0.01 & 0.00 \\
\hline Max & 0.06 & 0.05 & 0.03 & 0.06 & 0.08 & 0.04 & 0.06 & 0.05 \\
\hline n & 9 & 10 & 16 & 11 & 20 & 19 & 11 & 16 \\
\hline
\end{tabular}

As the results is shown: there are $41.07 \%$ of companies with investment in environmental and protection is over-investment, while $58.93 \%$ of companies are under-investment. The reasons for the results summarized as follows:

(1) The errors in the data selection. As the information disclosure of investment in environmental and protection is not required to publish in listed company annual reports, together with accounting methodology of investment in environmental and protection is not perfect, the corporate environmental and protection information disclosure at different levels of detail make the data of investment in environmental protection more difficult to collect. Some companies combine all technical innovation investment of the year, and therefore we cannot obtain accurate environmental protection investment, which makes the existence of a certain error in part of the data set.

(2) Policy influence. China have begun to implement energy conservation policy in June 2007, and then in this text we select the 2004-2010 as observation years, However, in terms of investment in environmental and protection, Most enterprises less invested in environmental and protection before 2007, but increased in investment after that.

(3) The data of investment in environmental and protection distortion. At present, investment inefficiency in environmental and protection leads to "fake hot" in environmental and protection investment, masking the grim reality that investment in China's environmental pollution control is insufficient. This is one of the main reasons that can explain the emissions of major pollutants and other environmental goals not being achieved.

\subsubsection{Results}

Table. 5 reports details on regression results of the investment environmental protection model, from which we can find the coefficients of INVt-1 are different from the expected ones, and environmental protection investment in the last year has a negatively impact on that in this year. Summarized for the following reasons:

(1) Select a particular industry. We select a sample of coal mining company listed in the Shanghai and Shenzhen A-share, then screen data, and because the range of the sample is small, with varying levels of details on environmental information disclosure of a lot of corporate, which may make the regression results special.

(2) The special characteristics of environmental investment. The investment in environmental protection is different from fixed-asset investment, and the benefits for companies from environmental protection investment is far less that from direct investment in fixed assets, so companies will not continue investing in environmental protection, and also will not continuously increase the investment.

(3) The policy impacts. In June 3, 2007, the state issued the "Circular of the State Council on the issuance of a comprehensive energy conservation work," which is the first Circular on energy saving and emission reduction and reflects that the national attaches importance to environmental protection. Under the supervision of the policy, it will be the important work of energy saving and emission reduction that curb excessive growth of high energy consumption and high pollution industries in the future, speed up eliminating backward production capacity, speed up the adjustment of energy structure. With energy conservation efforts to be strengthened, and provisions of environmental indicators continually increasing, companies that did not invest in environmental protection before 2007, must performed environmental protection investment next year, and even strengthen the investment.

Table 5. Regression results of the environment investment in the model

\begin{tabular}{|l|l|l|l|l|l|}
\hline Variable & $\begin{array}{l}\text { Expected } \\
\text { signs }\end{array}$ & \multicolumn{2}{|l|}{$\begin{array}{l}\text { Growth } \\
\text { (Tobin's Q) }\end{array}$} & \multicolumn{2}{l|}{$\begin{array}{l}\text { Growth } \\
\text { (Tobin's Q) }\end{array}$} \\
\hline Intercept & & 0.01 & $(0.3)$ & 0.013 & $(0.7)$ \\
\hline Grow $_{\mathrm{t}-1}$ & + & -0.01 & $(-1.6)$ & -0.008 & $(-1.3)$ \\
\hline Lev $_{\mathrm{t}-1}$ & - & -0.01 & $(-1.1)$ & -0.011 & $(-1.1)$ \\
\hline Cash $_{\mathrm{t}-1}$ & + & 0.03 & $(0.2)$ & -0.002 & $(-0.1)$ \\
\hline Age $_{\mathrm{t}-1}$ & - & -0.01 & $(-1.2)$ & -0.001 & $(-0.6)$ \\
\hline Size $_{\mathrm{t}-1}$ & + & 0.02 & $(0.7)$ & 0.001 & $(0.3)$ \\
\hline RET $_{\mathrm{t}-1}$ & + & 0.03 & $(1.4)$ & 0.003 & $(0.9)$ \\
\hline $\mathrm{INV}_{\mathrm{t}-1}$ & + & $-0.24 * *$ & $(-2.1)$ & $-0.2 * *$ & $(-2.2)$ \\
\hline Year & & $\mathrm{NO}$ & YES & & \\
\hline $\mathrm{N}$ & & 112 & 112 & & \\
\hline Adj-R & & $0.057 \%$ & $0.026 \%$ & & \\
\hline
\end{tabular}

3 THE ADVICE OF IMPROVING THE EFFICIENCY OF THE ENVIRONMENTAL PROTECTION INVESTMENT

\subsection{Strengthen the effective supervision on environmental protection fund and facilities}

The above analysis shows that our coal mining of listed corporations in the investment process. Due to 
a lack of scientific standard of environmental protection investment benefit evaluation system, $41.07 \%$ of observations with an excessive investment performance, and $58.93 \%$ of observations with an insufficient investment performance. What we suggest is: setting up a scientific and standardized environmental protection investment benefit evaluation system as soon as possible; protecting the environment construction project introduced the input-output economic accounting mechanism; setting up a government environmental protection financial the accounting system and a central and local financial expenditure budget; and gradually establishing environmental protection. This kind of environmental protection in the coal mining project investment and development process is of great importance to our coal firms.

\subsection{Economic policies that promote environmental protection investment}

Firstly, reform the coal mining enterprise infrastructure management in tax policy. Giving tax credit, pre-tax loans. Stimulate the enterprise proceed environmental protection facilities investment positively through the preferential policies.

Secondly, optimize the environmental protection investment structure. The environmental protection investment must be tilt to environmental technology research and development.

Finally, speed up the development of environmental protection industry. Formulate preferential policies, and to further improve the environmental protection products and environmental engineering quality and technology level, to have the capacity to produce advanced and reliable performance and efficiency of the environmental protection product enterprise, in fixed assets investment etc should be supported priority, and promote environmental protection industry scale form a scale.

\subsection{Implementation of diversification of environmental protection investment, promotion on environmental protection and diversification of financing source}

The implementation of the environmental protection investment diversification, channels and mode diversification is the future of China's coal mining enterprises and other enterprises in China environmental protection investment financing for the main way. The government should encourage private capital to join, and attract foreign investment, to create and market economic adaptation of the environmental protection investment mechanism, realize the diversification of investment in environmental protection diversity, operation subject entrepreneurial.

In addition, to expand its environmental protection financing channels, can use bond, stock, entrepreneurial plate and BOT (the constructionown-business-transfer) and so on which are the new capital market financing ways.

\section{CONCLUSIONS}

This paper finds that in the 2004-2010 period, $41.07 \%$ of the sample observations have invest more on environment protection and treatment, that is over-investment; while the other $58.93 \%$ have an under-investment effect. Since the energy conservation and emission reduction policies implemented, investment on environmental protection and treatment has increased sharply. However, according to the government aim at emission reduction, "ensure the environment protection investment growth rate higher than growth rate of GDP in China", put forward by Wen Jiabao, president of China Government, the firms in China has a long way to practice and adjust environment protection target.

\section{REFERENCES}

[1] Richardson, S. 2006. Over-investment of Free Cash Flow. Review of Accounting Studies.11: 159-189.

[2] Wang Chengfang, Luo Mingqi, Zhang Sheng and Zhang Min.2009. Investment Efficiency, Enterprise Property Right and Top Management Turnover. Journal of Shanghai Lixin University of Commerce, 2010 (1):37-47

[3] Zhang Bin, Zuo Hui. Sustainable Energy Utilization, Environmental Governance and Endogenous Growth. China Population Resources and Environment, 2007 (5): 27-32.

[4] Zhang Gong, Song Xian. Measuring Inefficient Investment by Listed Companies in China: Overinvestment or Underinvestment? Accounting Research, 2009 (5): 69-77. 